\title{
Cranial Characteristics, Maxillofacial, and Skull Base Structure of Non- Human Primate (Adult Macaca fascicularis): A Preliminary Study for Cranial Craniotomy Model
}

\author{
Hendrikus Masang Ban Bolly, ${ }^{1,2,4}$ Astrina Rosaria Indah, ${ }^{1,3}$ Ahmad Faried, ${ }^{4,6}$ Muhammad Zafrullah Arifin, \\ Rachmawati Noverina, ${ }^{5}$ Firman Fuad Wirakusumah ${ }^{6}$ \\ ${ }^{1}$ Faculty of Medicine Universitas Cenderawasih Jayapura, Papua, Indonesia, ${ }^{2}$ Graduate School of Biomedical \\ Sciences Master Program, Faculty of Medicine Universitas Padjadjaran Bandung, Indonesia, ${ }^{3}$ Doctoral Program \\ of Biomedical Sciences Master Program, Faculty of Medicine Universitas Padjadjaran Bandung, Indonesia, \\ ${ }^{4}$ Department of Neurosurgery Faculty of Medicine Universitas Padjadjaran/Dr. Hasan Sadikin General Hospital \\ Bandung, Indonesia, ${ }^{5} \mathrm{PT}$. Biofarma (Persero), Bandung, Indonesia, ${ }^{6}$ Stem Cell Working Group, Faculty of \\ Medicine Universitas Padjadjaran, Bandung, Indonesia
}

\begin{abstract}
The use of non-human primate (NHP) animal models, which anatomical and physiological similarities to human, is important for the sake of learning the anatomical properties. This study aimed to characterize the cranial, maxillofacial, and skull base structures of non-human primates as a potential model suitable for a cranial craniotomy model. Adult Macaca fascicularis (MF) skulls classified asspecificpathogen-free for TB, SIV, SV40, Polio, Foamy virus and Herpes B virus from PT Bio Farma (Persero) Animal Lab. Library were used to represent the anatomical model.The open access database from Mammalian Crania Photographic Archive $2^{\text {nd }}$ Edition (MCPA2) was used for cranial characterization analysis. This study was performed at the Department of Neurosurgery, Dr. Hasan Sadikin General Hospital and the Animal Laboratory of PT. Biofarma (Persero) from November 2018 to January 2019. The skull base structures were assessed for its analogies with its human counterpart. Comparison by $t$-student analysis between male and female skulls shows the mean male cranial length (CL) is greater than in female ( 116.68 vs $102.50 \mathrm{~mm}$ ), with $\mathrm{p}=0.000$; the mean male bizygomatic width (BZB) is greater than in female (79.30 vs $69.70 \mathrm{~mm}$ ) with $\mathrm{p}=0.001$; the mean male posterior cranial breadth (CBN) is greater than in female ( 63.40 vs $58.79 \mathrm{~mm}$ ) with $\mathrm{p}=0.019$; and the mean male cranial base length (CBL) is greater than in female ( 63.32 vs $57.55 \mathrm{~mm}$ ), with $\mathrm{p}=0.001$. The skull of MF is suitable for Neurosurgery and Neuroscience study since the MF cranial characterization and structure are similar to that of human. Its structure is ideal for performing craniotomy since it has several characteristics such as cranial vault, maxillofacial structure with huge temporal muscle, and skull base structure.
\end{abstract}

Key words: Cranial measurement, maxillofacial and skull base structure, non-human primate

\section{Karakteristik Kranium, Maksilofasial, dan Struktur Dasar Tengkorak Non- human Primate Macaca fascicularis dewasa: Studi Pendahuluan untuk Model Craiotomi Kranium}

\section{Abstrak}

Penggunaan hewan model berasal dari primata bukan-manusia (NHP), dimana secara anatomis dan fisiologis mirip dengan manusia, sangat penting untuk dapat mempelajari struktur anatominya. Penelitian ini bertujuan untuk karakterisasi struktur kranium, maksilofasial dan dasar tengkorak primata (Non-human Primate) yang berpotensi sebagai model penelitian kraniotomi. Tengkorak dewasa Macaca fascicularis (MF) dari Laboratorium Hewan PT Biofarma (Persero), bebas infeksi TBC, SIV, SV40, Polio, Foamy Virus, dan Herpes B digunakan sebagai model anatomi. Basis data terbuka Mammalian Cranial Photographic Archive $2^{\text {nd }}$ Edition (MCPA2) digunakan untuk analisis kranium. Penelitian dilakukan di Departmen Bedah Saraf RSHS dan Laboratorium Hewan PT. Biofarma pada November 2018-Januari 2019. Struktur tengkorak MF dipelajari analogi seperti pada struktur tengkorak manusia. Analisis uji-t tengkorak jantan dan betina menunjukan rerata panjang kranial (Cranial length, CL) jantan lebih panjang dibanding betina (116.68 vs $102.50 \mathrm{~mm}, \mathrm{p}=0.000)$; rerata bizygomatic width (BZB) jantan lebih panjang dibanding betina (79.30 vs $69.70 \mathrm{~mm}, \mathrm{p}=0.001)$; rerata posterior cranial breadth $(\mathrm{CBN})$ jantan lebih panjang dibanding betina (63.40 vs $58.79 \mathrm{~mm}, \mathrm{p}=0.019)$; dan rerata cranial base length (CBL) jantan lebih panjang dibanding betina (63.32 vs57.55 mm, p=0.001). Tengkorak MF sesuai untuk berbagai penelitian bidang bedah saraf dan neurosains. Karakterisasi kranial dan strukturnya sama dengan yang dimiliki manusia. Struktur kranium MF merupakan model ideal untuk kraniotomi berdasar karakteristik tulang tengkorak, otot temporal besar pada maksilofasial, dan struktur dasar tengkorak.

Kata kunci: Pengkuruan kranium, non-human primate, struktur maksilofasial dan dasar tengkorak

Corresponding Author: Ahmad Faried, Department of Neurosurgery Faculty of Medicine Universitas Padjadjaran/Dr. Hasan Sadikin General Hospital Bandung, Jalan Pasteur No. 38 Bandung, West Java, Indonesia, Email: ahmad.faried@unpad.ac.id 


\section{Introduction}

The use of non-human primate (NHP) animal models is important for the sake of learning in vivo phenomenon, given its biological and anatomical properties are closely related to human primate counterpart. NHP has anatomical and physiological similarities to human that results of research in NHP will have significant relevance to humans (Figure 1), particularly in medicine filed. ${ }^{1}$ Members of the European Parliament conservation status based on the Convention on International Trade in Endangered Species of Wild Fauna and Flora (CITES) includes the NHP in Appendix II category, which means that these animals can be traded without damaging their survival by not retrieving them directly from their natural habitat as well as by following the international trade regulations and monitoring the trade in these animals. ${ }^{2}$ The Macacafascicularis skulls are similar to other species of Macaque in their anatomical landmark. ${ }^{3}$ This study used the NHP Macacafascicularis (MF) skulls to characterize the cranial, maxillofacial, and skull base structures to assess their potential suitability as a cranial craniotomy model.

\section{Methods}

This study was approved by the Ethics Committee of the Institutional of Animal Care and Use Ethics Commission (IACUC) of PT Bio Farma (Persero) through the issuance of the ethical clearance No. 01/IACUC-BF/III/2017 with a validity period of 2 years, i.e. between April 14, 20177 to 2019 . This study was performed at the Department of Neurosurgery, Dr. Hasan Sadikin General Hospital and the Animal Laboratory of PT.Biofarma (Persero) during December 2018 to January 2019.

The specimens of adult Macacafascicularis skull (Figure 2A-C) belong to PT. Biofarma (Persero) Animal Lab and were taken from healthy donors (male, free from specific pathogens such as TB, SIV, SV40, Polio type 1,2,3, Foamy virus, and Herpes B virus.

Data on NHP cranium shown in Table 1 were obtained from the Mammalian Crania Photographic Archive Second Edition (MCPA2), as revised on December 1, 2005, as accessed at http://1kai.dokkyomed.ac.jp/mammal/en/ species_all/macaca_fascicularis.html. Each NHP cranium, which was placed horizontally, was photographed from 6 different angles (anterior, posterior, left, right, superior, and inferior) at a long distance using a camera with telephoto or telemacro lens. The long-distance shot decreases perspective distortion that lead to measurement errors when studying cranial profiles. For the cranial images in which the anatomical direction was deviated from the lens' optical axis due the technical inaccuracy, adjustments were applied repeatedly in the 3D rotations on the cranium's anatomical axes until the setting error was minimized. No digital enhancement was applied in image capture where the results were saved in a JPG compressed format at 6 megapixel resolution. The high resolution images enable specific observation of characteristics in details and comparisons of images on a computer screen. Granial length (CL) was defined as maximum length of neurocranium in the mid sagittal plane, which measured using a caliper from nasion. Zygomatic breadth was defined as bizygomatic width (BZB) from zygion to zygion while posterior cranial breadth was defined as maximum breadth width at lateral nuchal line (CBN). Furthermore, nasion to basion was defined as cranial base length (CBL) from anatomical landmark of nasion in front of basion in the skull base. These measurements are illustrated in Fig.3A, B.

\section{Results}

Based on Table 1, there were 24 adult MF specimens, comprised of 15 male (62.5\%) and 9 female $(37.5 \%)$ speciments. There were 1.67 times more male than female MF cranials measured in our study.

The overall shortest cranial length (CL) size was $98.9 \mathrm{~mm}$ (DKY_2616) and the longest was $131.5 \mathrm{~mm}$ (DKY_2678). Meanwhile, the shortest and the longest bizygomatic widths (BZB)(DKY_1556) were $64 \mathrm{~mm}$ and $92.2 \mathrm{~mm}$ (DKY_2678), respectively. It was also revealed that the shortest posterior cranial breadth (CBN) was $55.1 \mathrm{~mm}$ (DKY_1057) while the longest was $72.3 \mathrm{~mm}$ (DKY_0989). The shortest cranial base length (CBL) was $50 \mathrm{~mm}$ (DKY_2047) while the longest was $69 \mathrm{~mm}$ (DKY_2829).

In adult MF males, the shortest CL size was $105.2 \mathrm{~mm}$ (DKY_2447) and the longest was 131.5 mm (DKY_2678), with the mean \pm standard deviation (SD) of $116.7 \pm 7.8$, as shown in Table 2 while the shortest BZB was 66.9 mm (DKY_1057) and the longest was $92.2 \mathrm{~mm}$ (DKY_2678), with mean of $79.3 \pm 6.45$. Next. the shortest CBN was $55.1 \mathrm{~mm}$ (DKY_1057) and the longest was 72.3 
Bolly, et al: Cranial Characteristics, Maxillofacial, and Skull Base Structure of Adult Macaca fascicularis

Table 1 Specimen Code (Sex, Adult) from MCPA2 Database (see Material Methods for detail)

\begin{tabular}{|c|c|c|c|c|c|}
\hline \multirow[b]{2}{*}{ MF Identity } & \multirow[b]{2}{*}{ Sex } & \multicolumn{4}{|c|}{ Measurements (mm) } \\
\hline & & $\begin{array}{l}\text { Maximum } \\
\text { Length (CL) }\end{array}$ & $\begin{array}{c}\text { Zygomatic } \\
\text { Breadth } \\
\text { (BZB) }\end{array}$ & $\begin{array}{l}\text { Posterior Cranial } \\
\text { Breadth (CBN) }\end{array}$ & $\begin{array}{c}\text { Nasion -Basion } \\
\text { (CBL) }\end{array}$ \\
\hline DKY_0727 & Male & 119.4 & 80.4 & 66.7 & 64.0 \\
\hline DKY_0989 & Male & 131.3 & 90.3 & 72.3 & 65.0 \\
\hline DKY_0995 & Male & 121.5 & 83.4 & 67.3 & 67.4 \\
\hline DKY_1057 & Male & 107.5 & 66.9 & 55.1 & 56.0 \\
\hline DKY_1229 & Female & 106.0 & 72.4 & 58.2 & 57.9 \\
\hline DKY_1556 & Female & 101.6 & 64.0 & 56.2 & 56.0 \\
\hline DKY_2008 & Male & 114.6 & 79.5 & 66.3 & 63.7 \\
\hline DKY_2047 & Female & 100.1 & 67.6 & 55.9 & 50.0 \\
\hline DKY_2122 & Female & 102.9 & 67.6 & 57.5 & 60.8 \\
\hline DKY_2447 & Male & 105.2 & 72 & 56.5 & 57.9 \\
\hline DKY_2581 & Male & 109.2 & 75.3 & 60.5 & 60.8 \\
\hline DKY_2614 & Female & 104.0 & 71.8 & 62.3 & 59.7 \\
\hline DKY_2615 & Female & 105.4 & 77.1 & 63.4 & 59.5 \\
\hline DKY_2616 & Female & 98.9 & 71.6 & 59.0 & 58.3 \\
\hline DKY_2630 & Male & 117.7 & 78.6 & 63.1 & 63.9 \\
\hline DKY_2646 & Male & 121.5 & 77.2 & 62.9 & 66.4 \\
\hline DKY_2678 & Male & 131.5 & 92.2 & 71.8 & $\mathrm{~N} / \mathrm{A}$ \\
\hline DKY_2829 & Male & 111.1 & 81.8 & 61.9 & 69.0 \\
\hline THK_0177 & Female & 99.0 & 67.1 & 57.7 & 58.1 \\
\hline THK_0923 & Female & 104.6 & 68.1 & 58.9 & 57.7 \\
\hline THK_1342 & Male & 110.9 & 76.1 & 63.3 & 60.2 \\
\hline THK_1345 & Male & 112.4 & 74.2 & 58.1 & 58.0 \\
\hline THK_1371 & Male & 116.1 & 81.8 & 65.3 & 66.0 \\
\hline THK_1372 & Male & 120.4 & 79.9 & 59.9 & 66.5 \\
\hline
\end{tabular}

mm (DKY_0989), with a mean of 63.45 while the shortest CBL was $56 \mathrm{~mm}$ (DKY_1057) and the longest was $69 \mathrm{~mm}$ (DKY_2829), with a mean of 63.2 \pm 3.9 .

In adult MF females, the shortest CL size was 98.9 mm (DKY_2616) and the longest was 105.4 mm (DKY_2615), with the mean of $102.5 \pm 2.72$ as shown in Table 2 while the shortest BZB was $64 \mathrm{~mm}$ (DKY_1556) and the longest was $72 \mathrm{~mm}$ (DKY_1229), with a mean of $69.7 \pm 3.88$. Furthermore, the shortest CBN was $55.9 \mathrm{~mm}$ (DKY_2047) and the longest was $63.4 \mathrm{~mm}$ (DKY_2615), with a mean of $58.8 \pm 2.5$ while the shortest CBL was $50 \mathrm{~mm}$ (DKY_2047) and the longest was $60.8 \mathrm{~mm}$ (DKY_2122), with a mean of \pm 3.1 .
When comparing male vs female measurements, it was discovered that the mean male CL was greater than that of females (116.68 vs 102.50$)$ and the difference was significant $(\mathrm{p}=0.000)$. A significant different $(\mathrm{p}=0.001)$ was also found between the mean male and female BZB where the male one was greater than the female one (79.30 vs 69.70$)$. Other significant differences were also seen between the mean male and female CBN (63.40 vs 58.79), in which the male one was greater, as greater than female $(p=0.019)$ and between the male and female CBL where the male one was greater (63.32 vs 57.55 ) $(\mathrm{p}=0.001)$.

The primary bones of the maxillofacial structures are maxilla, mandible, small frontal 
Table 2 Cranial Characteristics of 24 Specimens of Adult Macaca Fascicularis

\begin{tabular}{cc}
\hline $\begin{array}{c}\text { Cranial Characteristics } \\
\text { (n=24 (Adult)) }\end{array}$ & $\begin{array}{c}\text { Mean in mm } \\
\text { 土 standard } \\
\text { deviation }\end{array}$ \\
\hline Maximum Length (CL) & $116.7 \pm 7.8$ \\
Male (25) & $102.5 \pm 2.72$ \\
Female (9) & \\
Zygomatic Breath (BZB) & $79.3 \pm 6.45$ \\
Male (25) & $69.7 \pm 3.88$ \\
Female (9) & \\
Posterior Cranial Breadth & \\
(CBN) & $63.4 \pm 5$ \\
Male (25) & $58.8 \pm 2.5$ \\
Female (9) & \\
Nasion-Basion (CBL) & $63.2 \pm 3.9$ \\
Male (25) & $57.6 \pm 3.1$ \\
\hline Female (9) &
\end{tabular}

bone, nasal bone, and zygoma and the primary bones that constructs the facial bones are one vomer, two maxilla bones, one mandible, two nasal bones, two palatine bones, two lacrimal bones, two zygomatic bones and two nasal concha bones (Figure 2AB).

The skull base structure is divided into 3 areas: (i) anterior fossa, (ii) middle fossa, and (iii) posterior fossa. The bones that primarily constructs the skull base are frontal bone, sphenoid bone, temporal bone, and occipital bone. In details, the skull base is constructed of the crista galli, ethmoid bone, roof of orbita, sella turcica, lesser wing of sphenoid bones, petrous bones, and the posterior wall of petrous bones (Figure 2C).

\section{Discussion}

Macacafascicularis, also known as longtailed monkeys, cynomolgus, or crab-eating monkeys, is native to Southeast Asia (Indonesia, Philippines and Malaysia). These monkeys are found throughout Indonesia such as in Java, Sumatra, Bali and Kalimantan. These monkeys live in groups, with the dominance of male monkeys as group leaders. MF's main habitats are mangrove areas, coastal areas, and forests up to 2000 meters above sea level. ${ }^{3,4}$

MF has the ability to see using both eyes at the same time (binocular vision) and it has a muscular tail that is covered by short hairs. The length of this species' tail usually ranges from $400-565 \mathrm{~mm}$. Head and body length of Macacafascicularis ranges from 350 to $455 \mathrm{~mm}$. In relation to the animal models used in this study, the Macaque brain is also protected by a skull and three covering layers that are very

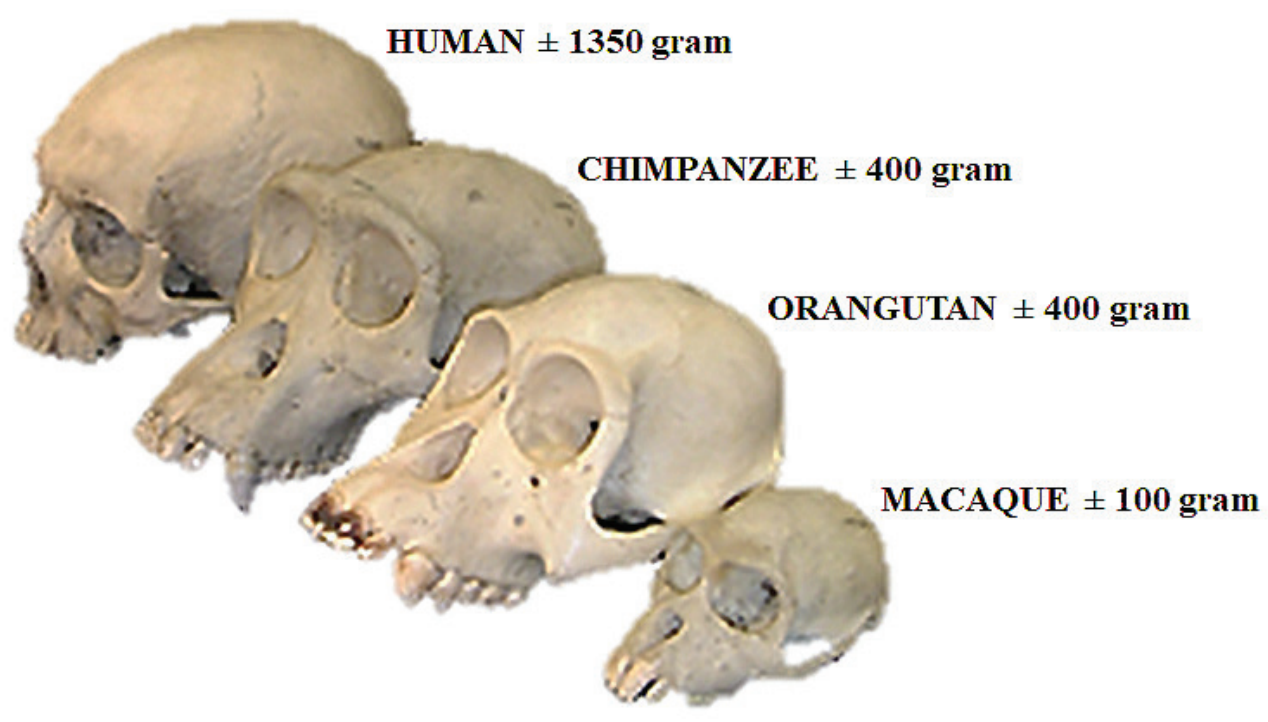

Figure 1 Comparable Size and Weight between g Human Primate Brain and Its Non-Human Primate Counterpart. Figure Shows the Size and Weight of Human, Chimpanzee, Orangutan, and Macaque Species Skulls 

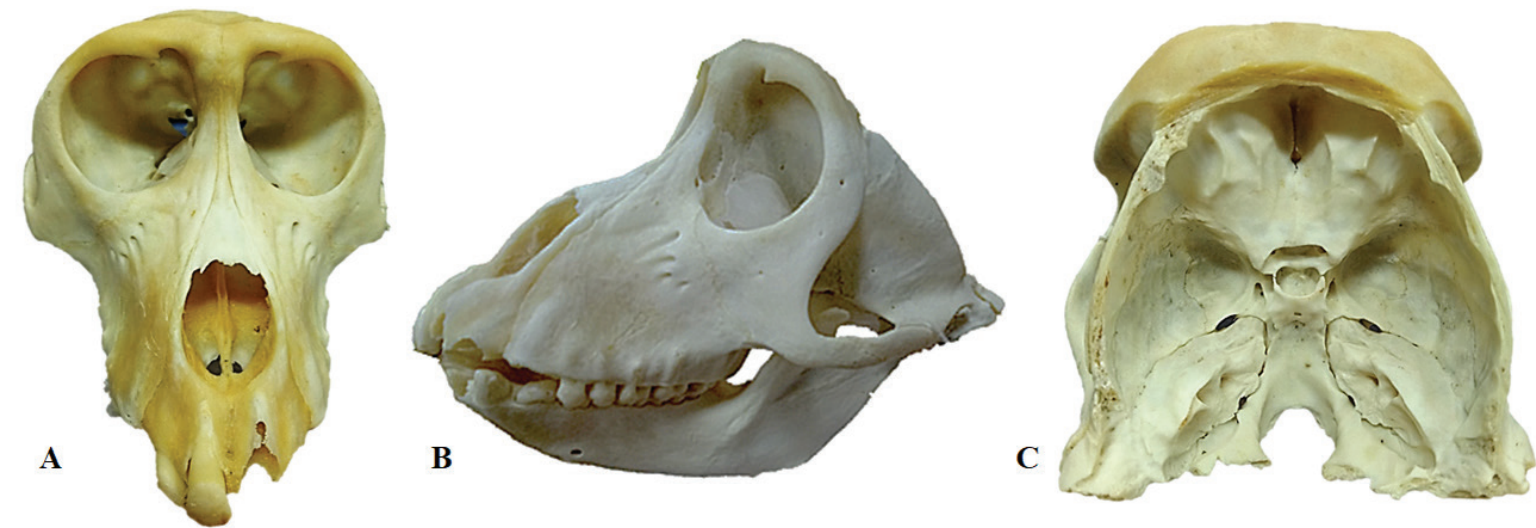

Figure 2 Photograph of An Adult Macacafascicularis Skull; Anterior (A); Sagittal (B); and Axial Views that Expose the Skull Base Structures (C)

A

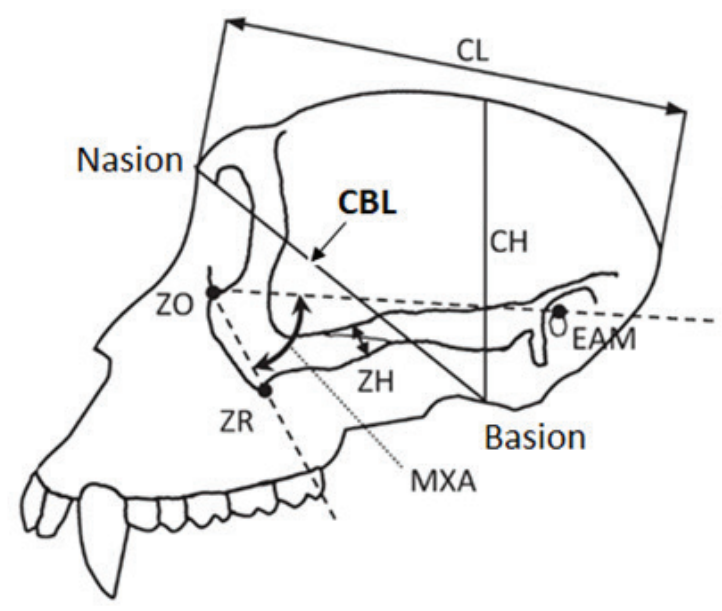

B

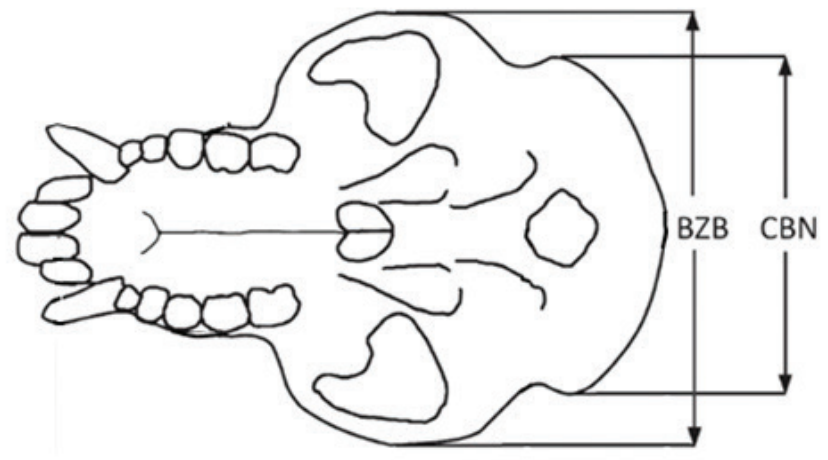

Figure 3 Illustration of The Cranial Length (CL), Bizygomatic Width (BZB), Cranial Breadth Nuchal Line (CBN) and Cranial Base Length (CBL)

Cranial height $(\mathrm{CH})$ from basion to bregma. Zygomatic height $(\mathrm{ZH})$ at temporozygomatic suture (TZS) minimum distance measured from superior zygomatic process to inferior temporal process across middle TZS. Maxillary angle (MXA): the angle taken between the length from zygomaticomaxillary suture (ZMS) at inferior orbital margin (ZO) to ZMS at root of zygomatic arch (ZR) and the length from ZMS at inferior orbital margin (ZO) to the middle of the external auditory meatus at the upper margin of the meatus (EAM). 
strong. The layers are, from the outside to inside, duramater, arachnoid, and pyramid layers. The duramater is composed of solid collagen connective tissue. ${ }^{4}$

It was suggested in a previous study that the cranial length of MF species, specifically Macaca fuscata, is between $100.5 \mathrm{~mm}$ to 119.4 $\mathrm{mm}$ in adult female MF whereas in the male counterparts, the length is $118.6 \mathrm{~mm}$ to 133.1 $\mathrm{mm} .{ }^{3}$ The weight of the Macaque brain tissue is around 100 grams. ${ }^{5} \mathrm{MF}$ has the same anatomical and physiological structures as humans. The visual complex and motoric control in Macaque have the same physiological and anatomical control as humans. ${ }^{5}$

Previous study indicates that the cranial dimensions can show age-related changes with an increasing pattern from young adulthood (7.0 years) to mid-adulthood (13.3-19.0 years in males and 19.7-22.6 years in females) and then become stagnant from mid-adulthood to very old age (26.9 years or more) or increasing from young adulthood to very old age. ${ }^{6,8}$ This study only used young adulthood macaques with the following results: the male CL is significantly greater than female (116.68 vs $102.50 ; p=0.000$ ); the mean male BZB is significantly greater than the female (79.30 vs $69.70 ; p=0.001$ ); the mean male CBN is significantly greater than female (63.40 vs 58.79; $\mathrm{p}=0.019$ ); and the mean male CBL is also significantly greater than that of females $(63.32$ vs $57.55 ; \mathrm{p}=0.001$ ). Collectively, this shows that cranial dimensions in male Macaca fascicularis is greater than those of its female counterpart, which is similar to human beings. ${ }^{7,8,11,12}$

As for maxillofacial bones and skull base structures, a complete maxillofacial primary bones are observed in Macaca fascicularis, i.e. maxillae, mandible, small frontal bone, nasal bone, and zygoma along with complete skull base primary bones consisting of frontal bone, sphenoid bone, temporal bone, and occipital bone., ${ }^{9,10,13}$ Therefore, its structures are ideal for performing craniotomy since it has several characteristics, such as the cranial vault, maxillofacial regions with huge temporal muscle, and skull base structures that resemble the anatomical structure of human-primate. ${ }^{9,11,12}$ The skull houses and protects the brain and sensory organs, supports critical functions, and provides a framework onto which muscles and other soft tissue can attach to. ${ }^{15,16}$ Even the histological structures of human meninges layer that consist of duramater, arachnoid, and piamater are also found in $\mathrm{MF}^{8,16}$ Soft tissue structures are also present within the cranium, such as the dural septa (tentorium cerebelli, falxcerebri, and falxcerebelli) and septal cartilage. It has been suggested that these structures may play a functional and important roles in craniofacial form. ${ }^{14,15,16}$

Cranial anatomy has a central role in studies of systematics, phylogeny, and functional anatomy in primate and human. ${ }^{12}$ In conclusion, this study found that the MF skull is a miniature scale of human skull that its functional anatomy is suitable for neurosurgery and neuroscience studies.

\section{Acknowledgment}

This study was supported by Grants-in-Aid from the Ministry of Research, Technology and Higher Education of the Republic of Indonesia No. 06/E/ KPT/2019 (World Class Research).

\section{References}

1. Moshe BM. Understanding animal research: primates in medical research. London: Understanding Animal Research; 2013. p. 9-11.

2. Convention on international trade in endangered species of wild fauna and flora. [cited 2019 January 20]. Available from: https://www.cites.org/eng/disc/ text.php.

3. Fooden J. Comparative review of fascicularisgroup species of macaques (primates: macaca) in Fieldiana Zoology, USA: Field Museum of Natural History; 2006. p. 7-11.

4. Karyani RA. Perkembangan sel-sel gonadotropin adenohipofise monyet ekor panjang (macaca fascicularis) pada periode pra- dan pascalahir. Bogor: Institut Pertanian Bogor; 2008.

5. Weatherall D. The use of non-human primates in research. UK: The Academy of Medical Sciences; 2006. p. 59-84.

6. van Minh N, Mouri T, Hamada Y. Aging-related changes in the skulls of Japanese macaques (Macaca fuscata). Anthropological Science. 2015;123(2):107-19.

7. Lalwani M, Yadav J, Arora A, Dubey BP. Sex Identification from cranial capacity of adult human skulls. J Indian Acad Forensic Med. 2012;34(2):128-31.

8. Schillaci MA. Latitudinal variation in cranial dimorphism in Macaca fascicularis. Am.J.Primatol. 2010;72152-60

9. Fitton LC, Shi JF, Fagan MJ, O’Higgins 
P. Masticatory loadings and cranial deformation in Macaca fascicularis: a finite analysis sensitivity study. J Anat. 221(1):5568.

10. Curtis N, Witzel U, Fagan MJ. Development and three-dimensional morphologyof the Zygomaticotemporal suture in primate skulls. Folia Primatol (Basel). 2014;85(2):77-87.

11. Mouri T. Multivariate cranial ontogenic allometries in crab-eating rhesus and Japanese macaques. Anthropol Sci. 1996; 104(4):281-303.

12. Fleagle JG, Gilbert CC, Baden AL. Primate cranial diversity. American Am J Phys Anthropol. 2010;142(4):565-78.

13. Ito T, Nishimura T, Takai M. Allometry and interspecific differences in the facial cranium of two closely related macaque species. Anat
Res Int. 2011;2011:849751.

14. Wang Q, Wood SA, Grosse IR, Ross CF, Zapata $\mathrm{U}$, Byron $\mathrm{CD}$, et al. The role of the sutures in biomechanical dynamic simulation of a macaque cranial finite element model: implications for the evolution of craniofacial form. Anat Rec (Hoboken). 2012;295(2):278-88.

15. Ross CF, Berthaume MA, Dechow PC, IriarteDiaz J, Porro LB, Richmond BG, et al. In vivo bone strain and finite-element modelling of the craniofacial haft in catarrhine primates. J Anat. 2011;218(1):112-41.

16. Curtis N, Witzel U, Fitton L, O'higgins P, Fagan M. The mechanical significance of the temporal fasciae in Macaca fascicularis: an investigation using finite element analysis. Anat Rec (Hoboken). 2011;294(7):1178-90. 